\title{
EVALUATION OF PASTURE SOIL PRODUCTIVITY IN THE SEMI-ARID ZONE OF BRAZIL BY MICROBIAL ANALYSES
}

\author{
Rômulo Gil de Luna ${ }^{1}$; Henrique Douglas Melo Coutinho ${ }^{2 *}$; Breno Machado Grisi ${ }^{1}$
}

${ }^{1}$ Programa Regional de Pós-Graduação em Desenvolvimento e Meio Ambiente, Universidade Federal da Paraíba, João Pessoa, PB, Brasil; ${ }^{2}$ Departamento de Ciências Físicas e Biológicas, Centro de Ciências Biológicas e da Saúde, Universidade Regional do Cariri, Crato, CE, Brasil.

Submitted: March 01, 2007; Returned to authors for corrections: October 16, 2007; Approved: July 17, 2008.

\begin{abstract}
The productivity of a pasture soil (caatinga) located in the region of São João do Cariri, PB, Brazil was evaluated based an the following microbiological parameters: biomass (measured by fumigation-incubation method), activity (estimated from basal respiration and cellulose decomposition rate), $\mathrm{qCO}_{2}$, and $\mathrm{C}_{\text {mic }}$ : $\mathrm{C}_{\text {org }}$ ratio. This analysis demonstrated that livestock management in the 'caatinga' is probably causing environment damage by affecting the soil properties, reducing the microbial biomass and soil respiration and increasing the $\mathrm{qCO}_{2}$, affecting the recovery of this ecosystem.
\end{abstract}

Key-words: semi-arid; biomass; microbial activity; pasture; caatinga.

The microregion of São João do Cariri, in the eastern Cariri region of Paraiba state, is undergoing desertification probably due to the extensive degradation of the 'caatinga' ecosystems, a typical shrub-steppe vegetation, spread over $1,000 \mathrm{~km}^{2}$. The local mean annual rainfall and temperature are $380 \mathrm{~mm}$ and $24.5^{\circ} \mathrm{C}$, respectively. Soil erosion caused by wind and the irregular but strong rain, and both uncontrolled overgrazing and exploitation of shrubbery mainly for firewood, are probably responsible for the 'caatinga' degradation (24). The 'caatinga' ecosystems, denominated in Cariri as pastures, are grazed mainly by goats (and some cattle), that eliminate fruits, seeds, seedlings, young shoots, twigs and leaves. The goats, after consuming the most edible parts of the majority of the plants, also ring-bark trees, torn away the cambial tissues and phloem from the woody xylem and effectively destroy the plants. It is quite impressive that the animals are raised free in the pastures and few cultivated plants (for forage) like Opuntia cacti, are kept in an enclosure, whose fence is constructed with every kind of avaiable wood. The shifting cultivation, where the remainders of crops (bean, maize, cassava) are burned, causes heavy loss of important nutrients (17).

The physical and chemical properties of soil are traditionally used for estimating the productivity of ecosystems. Soil microorganisms however, are more advantageous for evaluating soil management effects, since they reflect the possible modifications of soil, earlier than chemical analyses, and without background chemical effects (22).

Soil microbiota represent an important labile source of nutrients, mainly $\mathrm{C}, \mathrm{N}, \mathrm{P}$, and $\mathrm{S}$, being an immediate sink of these nutrients and an important agent of organic matter transformation. Microbial biomass is more visualized as a constant catalyst in the short term than over annual cycle basis, due to its seasonal fluctuations (25), and can be quite useful for evaluating management effects on soils, soil rehabilitation and productitity. Microbial carbon, particulary, has been used for estimating biomass, since it represents a mean of $47 \%$ of cell structure (16). In the microbial cell, ATP, C, N, P and S, keep a stable relation of 1:250:40:9:2.6 (21). Carbon balance in the soil, though not showing availability to the microbiota, is in agreement with the energy requirement of this live pool $(10,25)$. It has been quite useful in the studies of nutrient biogeocycling and on cropping and fertilizer practices of many agroecosystems and ecosystems of temperate and tropical soils $(18,27)$.

Microbial activity, estimated from basal respiration and cellulose decomposition rate (in situ), is another parameter that

*Corresponding Author. Mailing address: Universidade Federal da Paraíba - UFPB - Centro de Ciências Exatas e da Natureza - CCEN - Departamento de Biologia Molecular - DBM - Laboratório de Genética de Microrganismos - LGM. João Pessoa - PB CEP: 58051-900. E-mail: hdmcoutinho@gmail.com 
has been used for evaluating the microbiota condition in soils $(8,28)$. The metabolic coefficient estimated here, the specific biomass respiration rate or $\mathrm{qCO}_{2}$, based on concepts suggested by Anderson and Domsch (1993) (5), has been useful for observing the changes in the soil microbial populations under many effects $(3,12)$. Anderson and Gray (1991) (4) showed the usefulness of such coefficient to elucidate effects of environmental changes on microbial populations. In northeastern region of Brazil, $\mathrm{qCO}_{2}$ was used for evaluating the effect of vinasse in soil cultivated with sugarcane (19). The microbial biomass carbon as a percentage of total soil organic carbon (Biomass $\mathrm{C} /$ Total organic $\mathrm{C} \mathrm{X} \mathrm{100),} \mathrm{or} \mathrm{C}_{\text {mic }}$ : $\mathrm{C}_{\text {org ratio, }}$ has also been shown to reflect impacts on soil microbiota properties $(1,14,19)$.

In the present study the soil microbial biomass and activity, $\mathrm{qCO}_{2}$ and $\mathrm{C}_{\text {mic }}: \mathrm{C}_{\text {org }}$ ratio were estimated in the soil of two pastures in the semi-arid northeast region of Brazil in order to use these parameters as indicators of soil productivity.

The region of São João do Cariri is situated at longitude $36^{\circ} 32^{\prime} \mathrm{W}$ and latitude $07^{\circ} 24^{\prime} \mathrm{S}$; and altitude of 445 m.a.s. 1 . The mean annual rainfall and temperature are $380 \mathrm{~mm}$ and $24.5^{\circ} \mathrm{C}$, respectively, in agreement with its climate in Köppen classification (Bsh, very hot).

The field investigations were performed over the dry and rainy periods in São João do Cariri, from January to October/97. Two areas of 'caatinga' pastures with soil type Luvissol were selected; a pasture considered to be productive, designated as A, 'Fazenda Santana', and a less productive pasture, designated as B, 'Fazenda Poço das Pedras', both under continuous grazing, but respectively, for 25 and more than 40 years. They were chosen for also differing in plant density and diversity. Pasture A showed a greater density and biodiversity than $\mathrm{B}$, according to a preliminary observation performed (R.G. de Luna, unpublished data).

Soils samples were collected randomly from the mineral horizon $(0-20 \mathrm{~cm})$. Bulk soil samples were collected in the interspaces between trees in the sites that lacked vegetation. Each soil sample was a mixture of five sub-samples taken randomly in the selected area of $20 \times 20 \mathrm{~m}$. The soil sample preparation was done as described in Grisi et al. (1998) (12). Fumigated and unfumigated samples were maintained at $25^{\circ} \mathrm{C}$ during the pre-incubation and incubation periods.

Biomass carbon was measured by the fumigation-incubation method of Jenkinson and Powlson (1976) (15). The microbial biomass was obtained by $\mathrm{B}=(\mathrm{X}-\mathrm{x}) / \mathrm{K}_{\mathrm{C}}$, where $\mathrm{X}$ is the amount of $\mathrm{CO}_{2}$ produced int the 10 days following fumigation, $\mathrm{x}$ is the amount of $\mathrm{CO}_{2}$ from unfumigated samples in the period, and $\mathrm{K}_{\mathrm{C}}$ is the carbon from microbiota mineralized to $\mathrm{CO}_{2}$, a value here considered as 0.45 because the incubation was at $25^{\circ} \mathrm{C}(16)$ and the $\mathrm{pH}$ of the soils was above 4.5 (29). The $\mathrm{CO}_{2}$ evolved from the fumigated and unfumigated soil samples was trapped in an alkaline solution, during the incubation, and measured according to the method of Walter and Haber (1957) (31) and the technique described in Grisi (1978) (9).

The microbial activity was estimated from the basal respiration of the unfumigated soil samples and from the cellulose decomposition rate. The cellulose samples (hydrophyllic cotton) were treated as described elsewhere $(19,23)$.

The soil biomass specific repiration rate or $\mathrm{qCO}_{2}$, was calculated as suggested by Anderson and Domsch (1990) (3). The $\mathrm{qCO}_{2}$ value calculated from one hour of $\mathrm{CO}_{2}$ evolution from the unfumigated soil samples, representing the mean of the $24 \mathrm{~h}$ incubation period. Anderson and Domsch (1990) (3) used one hour obtained from the means of $10 \mathrm{~h}$ of $\mathrm{CO}_{2}$ evolution, because the technique they used allowed them this procedure. However, the $\mathrm{qCO}_{2}$ values here obtained, though higher than the ones reported by other authors, are valid for comparing the results of the present investigation.

The $\mathrm{C}_{\mathrm{mic}}$ : $\mathrm{C}_{\text {org }}$ ratio was determined by relating the biomass carbon obtained from each soil, to respective total organic carbon measured by the chemical analysis.

Mean values and standard deviation were generated to compare the microbiological parameters and the water content of the soil samples on the day they were collected.

The physical and chemical properties of soils A and B are given in Table 1.

Soils A and B had different textures. Soil A yields a better $\mathrm{CEC}$ and base saturation, with higher contents of $\mathrm{H}, \mathrm{Ca}, \mathrm{Mg}, \mathrm{S}$, $\mathrm{K}, \mathrm{Zn}, \mathrm{Cu}, \mathrm{Fe}, \mathrm{Mn}$ and $\mathrm{N}$ in the two seasons sampled. The $\mathrm{C}: \mathrm{N}$ ratio was 23:1 in $A$ and 20:1 in $B$, values close to 25:1 suggested by Paul and Clark (1989) (21) as the result of no net mineralization or immobilization. Soil water content was always higher in A (Table 2), where its clay texture (Table 1) and the necromass accumulated on its surface may contribute significantly. The physical and chemical properties of the soils show that pasture A had better fertility and productivity conditions than pasture B.

All results of biomass and basal respiration are given in milligrams of carbon from carbon dioxide per kilogram of ovendry soil (or $\mathrm{kg} \mathrm{CO}_{2}-\mathrm{C}^{-1}$ o. -d. soil).

Microbial biomass mean values in pasture A were $33,9 \mathrm{mg}$ of $\mathrm{CO}_{2}-\mathrm{C} \cdot \mathrm{kg}^{-1} \mathrm{o}$ - $\mathrm{d}$. soil, greater than in $\mathrm{B}, 13,4 \mathrm{mg}$ of $\mathrm{CO}_{2}-\mathrm{C} \cdot \mathrm{kg}^{-1} \mathrm{o}$. -d. soil. The higher biomass registered in the dry period in both areas is probably due to the greater values obtained from fumigated samples, compared to the values from unfumigated samples. It is known that spores are also included in this estimation, so contributing to high fumigated samples values and consequently, to biomass increase in dry period. According to Andrew and Harris' theory (6), biomass peak in soil A during the rainy period may indicate a predominance of K-strategists (mesophilic and thermophilic populations), results confirmed by comparing the means represented in Table 2 . It is important to observe from Tables 1 and 2, that in pasture A (a clay texture 
Table 1. Some physical and chemical properties of soils A ('Fazenda Santana') and B ('Fazenda Poço das Pedras'). Samples collected from mineral horizon $(0-20 \mathrm{~cm})$ during dry and rainy periods.

\begin{tabular}{ccccc}
\hline $\begin{array}{c}\text { Soil } \\
\text { property }\end{array}$ & $\begin{array}{c}\text { A(dry } \\
\text { period) }\end{array}$ & $\begin{array}{c}\text { A (rainy } \\
\text { period) }\end{array}$ & $\begin{array}{c}\text { B (dry } \\
\text { period) }\end{array}$ & $\begin{array}{c}\text { B (rainy } \\
\text { period) }\end{array}$ \\
\hline Texture & Clayey & Clayey & Medium & Medium \\
\hline $\mathrm{PH}$ & 6.4 & 6.0 & 6.3 & 6.1 \\
$\mathrm{CEC}, \mathrm{cmol} / \mathrm{kg}^{\mathrm{a}}$ & 25.58 & 22.11 & 8.07 & 11.30 \\
$\mathrm{H}$ “ & 1.40 & 1.56 & 1.34 & 1.32 \\
$\mathrm{Al}$ “ & 0.06 & 0.10 & 0.10 & 0.08 \\
$\mathrm{Ca}$ “ & 16.50 & 15.00 & 4.40 & 7.20 \\
$\mathrm{Mg}$ “ & 7.31 & 5.13 & 1.83 & 2.39 \\
$\mathrm{~S}$ “ & 24.12 & 20.45 & 6.63 & 9.90 \\
$\mathrm{P}, \mathrm{mg} / \mathrm{dm}^{3 a}$ & 11.15 & 12.26 & 3.17 & 3.34 \\
$\mathrm{~K}$ “ & 86 & 90 & 84 & 84 \\
$\mathrm{Na}$ “ & 21.50 & 20.00 & 21.00 & 22.50 \\
$\mathrm{Zn}$ “ & 1.5 & 1.6 & 1.2 & 1.4 \\
$\mathrm{Cu}$ “ & 1.2 & 1.4 & 0.8 & 1.0 \\
$\mathrm{Fe}$ “ & 260 & 280 & 230 & 220 \\
$\mathrm{Mn}$ “ & 41.0 & 33.00 & 22.00 & 19.00 \\
$\mathrm{~V}, \%$ a & 94.29 & 92.49 & 82.16 & 87.61 \\
$\mathrm{C}, \mathrm{g} / \mathrm{kg}$ & 12.99 & 12.68 & 9.88 & 8.83 \\
$\mathrm{~N}$, “ & 0.623 & 0.490 & 0.511 & 0.380 \\
$\mathrm{O} . \mathrm{M} ., \%$ & 2.72 & 2.40 & 2.48 & 2.32 \\
\hline
\end{tabular}

${ }^{\text {a }}$ Units recommended by Cantarella \& Andrade, 1992.

soil), the microbial biomass mean of the dry period was twice that of the microbial biomass mean of pasture $B$, a medium texture soil. Clay may have exerted a 'protecting action' on microbiota at elevated temperature in pasture A (during the dry period the temperature in the $0-5 \mathrm{~cm}$ deep in the 'caatinga' soil reaches $40^{\circ} \mathrm{C}$ ), an aspect reported by several authors but not confirmed in some Brazilian and English clay soils at $35^{\circ} \mathrm{C}$, under rigorously controlled temperature conditions $(11,12)$. This aspect deserves a more detailed investigation in situ.

We do not know from the literature, any result of biomass $\mathrm{C}$ from 'caatinga' soils, for a comparison. Soil from 'cerrado', of Minas Gerais State, for example, presented a biomass range from 16.1 to $36.6 \mathrm{mg} \mathrm{CO}_{2}$-C. $100 \mathrm{~g}^{-1} \mathrm{o}$. -d. soil, as determinated by Grisi (1997) (11), using fumigation-extraction method.

Microbial activity measured from basal respiration, was in $\mathrm{B}$ $5,7 \mathrm{mg}$ of $\mathrm{CO}_{2}-\mathrm{C}$. $\mathrm{kg}^{-1}$ o. $-\mathrm{d}$. soil, a range greater than found in $\mathrm{A}$ (4,8 mg CO $2-C . \mathrm{kg}^{-1}$ o. -d. soil) (Table 2). These results show clearly that the microbial populations of $\mathrm{B}$ invest most of their energy for maintenance, a typical condition of disturbed, stressed environment, as confirmed by the $\mathrm{qCO}_{2}$ values. Microbial activity estimated from cellulose decomposition rate was also higher in $\mathrm{B}$, in most of the determinations performed (Table 2). A phenomenon identified as contact surface, between soil particles and cellulose samples, may have occurred, since in B the coarse texture and less crumbs formed, rendered easier attack of the cellulose by microorganisms. Hassink (1994) (13) also observed a higher microbial activity in sandy loam soils than in a clay soil.

The $\mathrm{qCO}_{2}$ values obtained confirmed the microbial activity in $\mathrm{B}$, showing mean of $3,98 \mathrm{mg}$ of $\mathrm{CO}_{2}-\mathrm{C} . \mathrm{g}^{-} 1$ of biomass, higher than in A, which had mean of $0,69 \mathrm{mg}$ of $\mathrm{CO}_{2}-\mathrm{C}^{-1} \mathrm{~g}^{-1}$ of biomass C. $h^{-1}$ (Table 2). This result reinforces the fact that soil microbial populations of B use most of the carbon for their own maintenance. According to Smith et al. (1994)(26) the microbial processes in arid ecossystems are influenced by heterogeneously-spaced plants and abiotic variables and that their $\mathrm{qCO}_{2}$ estimates are twice of registered for other natural forest and grassland ecosystems.

The $C_{\text {mic }}$ : $C_{\text {org }}$ ratio confirmed that the most productive soil (A) stores more carbon in the biomass, while in $\mathrm{B}$ it is confirmed its use in maintenance. Luna and Grisi (1996) (19) also observed a higher $\mathrm{qCO}_{2}$ and a lower $C_{m i c}: C_{\text {org }}$ ratio in a less productive soil under sugarcane cultivation. Gorlach - Lira and Coutinho (2007) (7), working with microbial populational diversity in

Table 2. Microbiological parameters and soil water content (WT) of samples from areas A and B, measured during dry (D) and rainy (R) seasons.

\begin{tabular}{ccccccc}
\hline Area (Season) & MicrobialBiomass $^{\mathrm{a}}$ & Basal respiration $^{\mathrm{b}}$ & Decomposition rate $^{\mathrm{c}}$ & $\mathrm{qCO}_{2}{ }^{\mathrm{d}}$ & $\mathrm{C}_{\text {mic }}: \mathrm{C}_{\text {org }}$ & $\mathrm{WT}^{\circ}$ \\
\hline $\mathrm{A}(\mathrm{D})$ & $35,54 \pm 0,77$ & $5,1 \pm 0,31$ & $1.13 \pm 0,82$ & $0,16 \pm 0,4$ & $2.73 \pm 0,6$ & $3.9 \pm 1,5$ \\
$\mathrm{~A}(\mathrm{R})$ & $32,38 \pm 0,5$ & $4,5 \pm 0,38$ & $8.67 \pm 6,5$ & $1,20 \pm 0,49$ & $7.65 \pm 0,4$ & $10.5 \pm 1,25$ \\
$\mathrm{Mean}^{1}$ & $\mathbf{3 3 , 9} \pm \mathbf{0 , 0 8}$ & $\mathbf{4 , 8} \pm \mathbf{0 , 0 3}$ & $\mathbf{4 . 9 0} \pm \mathbf{3 , 7 7}$ & $\mathbf{0 , 6 9} \pm \mathbf{0 , 0 3}$ & $\mathbf{5 . 1 9} \pm \mathbf{2 , 4 6}$ & $\mathbf{7 . 2} \pm \mathbf{3 , 3}$ \\
$\mathrm{B}(\mathrm{D})$ & $17,3 \pm 0,75$ & $5,5 \pm 0,17$ & $1.61 \pm 0,96$ & $0,51 \pm 0,17$ & $1.75 \pm 0,76$ & $1.5 \pm 0,8$ \\
$\mathrm{~B}(\mathrm{R})$ & $9,5 \pm 0,23$ & $5,9 \pm 0,47$ & $12.02 \pm 9,03$ & $7,46 \pm 0,26$ & $1.07 \pm 0,27$ & $3.3 \pm 1,7$ \\
Mean B $^{1}$ & $\mathbf{1 3 , 4} \pm \mathbf{0 , 3 9}$ & $\mathbf{5 , 7} \pm \mathbf{0 , 0 2}$ & $\mathbf{6 . 8 1} \pm \mathbf{5 , 2 1}$ & $\mathbf{3 , 9 8} \pm \mathbf{0 , 0 5}$ & $\mathbf{1 . 4 1} \pm \mathbf{0 , 3 4}$ & $\mathbf{2 . 4} \pm \mathbf{0 , 9}$ \\
\hline
\end{tabular}

a - $\mathrm{mgCO}_{2}-\mathrm{C} . \mathrm{kg}^{-1}$ soil; b - mgCO 2 -C.kg ${ }^{-1}$ soil; c - Mg. ha ${ }^{-1} \cdot \mathrm{yr}^{-1} ; \mathrm{d}-\mathrm{mgCO}_{2}-\mathrm{C} . \mathrm{g}^{-1}$ biom; ${ }^{1}$ General means of dry and rainy periods; results followed by the same latter, in the lines. 
Caatinga soil showed that areas with more plants (as pasture A) presents a higher microbial population, linking the grazed areas with less productivity.

The parameters here studied, as also observed by other authors in similar environmental situations $(2,14)$, suggest that microbial populations of B are probably under stress, like the stress admitted by Wardle and Ghani (1995) (30). However, there is also the possibility that the present results give support to Odum's idea: 'repairing damage by disturbances requires diverting energy from growth and production to maintenace' (20). Opposite to such situation occuring in pasture B, in the productive pasture soil A the microbiota stores sufficient energy to increase in size and biodiversity. A long-term investigation would be necessary to define the nature of the pressure acting on the 'caatinga' pastures microbiota here studied. An useful discussion about the need for distinguishing stress from disturbance is provided by Wardle and Ghani (1995) (30), who criticize the use of $\mathrm{qCO}_{2}$, which does not provide a distinction between these two effects. However, this metabolic quotient has shown its applicability as an index of adversity of environmental conditions (30). We consider that such conditions exist in the pastures investigated in the present study, which main aspect is quite different from the explanation created for using $\mathrm{q} \mathrm{CO}_{2}$ as a bioindicator of ecosystem recovery after its disturbance.

The higher microbial biomass in the productive soil (A) suggests that its microbiota has more chances to increase, with greater benefit to the 'caatinga' ecosystem, than in the leess productive soil (B). The largest $\mathrm{qCO}_{2}$ and the smallest $\mathrm{C}_{\text {mic }}$ : $\mathrm{C}_{\text {org }}$ ratio in $\mathrm{B}$, corroborate with the opinion that the microbiota use their energy for maintenance, with less benefit to the 'caatinga' vegetation. The microbiological parameters used here have proved to be useful as bioindicators of pasture soil productivity in the 'caatinga' of the Brazilian semi-arid region. They may also reflect the environmental pressures to which the overgrazed 'caatinga' (B) is submitted, such as frequently prolonged dry periods that affect the microbiota os both pastures.

The need for shifting from the present management system of animal husbandry, allowing the native plants to complete their life cycle seems to be clear, mainly when there is a limited availability of nutrients to the microbiota (and consequently to the local flora) as in the less productive soil (B). However, any proposal to be accomplished must be pursued on a long-term basis, mainly due to the irregular rainfall in São João do Cariri region.

\section{ACKNOWLEDGEMENTS}

To the Forestry Engineer Nivaldo Maracajá Filho, for introducing us to the 'caatinga' of São João do Cariri. To CAPES ('Coordenação de Pessoal de Nível Superior') for the grant given to R.G. de Luna, to FUNCAP ('Fundação Cearense de apoio a
Pesquisa'), by the grant to H.D.M. Coutinho, to Usina Japungu administrtion, Municipality of Santa Rita, Paraíba State, for ordering the soil physical and chemical analyses performed by LAGRI-Camaragibe, State of Pernambuco. To Dr. Robert Coler (Professor Emeritus of Massachusetts University) for review of the manuscript.

\section{RESUMO}

\section{Avaliação da Produtividade de um solo de Pastagem na Zona do Semi - Árido Através de Análises Microbianas}

A produtividade de um solo de pastagem (caatinga) na região de São João do Cariri, PB, Brasil foi avaliado através dos seguintes parâmetros microbiológicos: biomassa (medidas pelo método de fumigação - incubação), atividade (estimada com base na respiração basal e taxa de decomposição de celulose), $\mathrm{qCO}_{2}$ e a razão $\mathrm{C}_{\text {mic }}$ : $\mathrm{C}_{\text {org. }}$. Estas análises demonstraram que o manejo de rebanhos na caatinga pode causar danos a este ambiente devido a modifícações das propriedades do solo como diminuição da biomassa microbiana e da atividade e aumento do $\mathrm{qCO}_{2}$, afetando a recuperação deste ecossistema.

Palavras - Chave: Semi-árido; Biomassa; Atividade microbiana; Pastagem; Caatinga.

\section{REFERENCES}

1. Anderson, T.H. (1998). The influence of acid irrigation and liming on the soil microbial biomass in a Norway spruce (Picea abies [L.] K.) stand. Plant Soil, 199, 117-122.

2. Anderson, T.H.; Domsch, K.H. (1989). Ratios of microbial biomass carbon to total organic carbon in arable soils. Soil Biol. Biochem., 21, 471-479.

3. Anderson, T.H.; Domsch, K.H. (1990). Application of ecophysiological quotients $\left(\mathrm{qCO}_{2}\right.$ and $\left.\mathrm{qD}\right)$ on microbial biomass from soils of different cropping histories. Soil Biol. Biochem., 22: 251255.

4. Anderson, T.H.; Gray, T.R.G. (1991). The influence of soil organic carbon on microbial growth and survival. In: Wilson, W.S. (ed.) Advances in Soil Organic Matter Research: the Impact on Agriculture and Environment. Redwood Press, Melksham, pp. 253-266.

5. Anderson, T.H.; Domsch, K.H. (1993). The metabolic quotient for $\mathrm{CO}_{2}\left(\mathrm{qCO}_{2}\right)$ as specific activity parameter to assess the effects of environmental conditions, such as $\mathrm{pH}$, on the microbial biomass of forest soil. Soil Biol. Biochem., 25: 393-395.

6. Andrews, J.H.; Harris, R.F. (1986). r- and k- selection and microbial ecology. In: Marshall, K.L. (ed.) Advances in Microbial Ecology. Plenum Press, New York, pp. 99-147.

7. Gorlach-Lira, K.; Coutinho, H.D.M. (2007). Population dynamics and extracellular enzymes activity of mesophilic and thermophilic bacteria isolated from semi-arid soil of Northeastern Brazil. Braz. J. Microbiol., 38: 135-141.

8. Gray, T.R.G. (1990). Methods for studying the microbial ecology of ecology of soil. In: Grigorova, R., Norris, J.R. (eds.) Methods in Microbiology. Cambridge University Press, Cambridge, pp. 310-342. 
9. Grisi, B.M. (1978). Método químico de medição da respiração edáfica: alguns aspectos técnicos. Ciência e Cultura, 30: 82-88.

10. Grisi, B.M. (1988). Biomassa e Necessidades Energéticas das Populações Microbianas do Solo. In: Moniz, A.C., Furlani, A.M.C., Furlani, P.R., Freitas, S.S. (eds.) A Responsabilidade Social da Ciência do Solo. Campinas. pp. 353-363.

11. Grisi, B.M. (1997). Temperature increase and its effect on microbial biomass and activity of tropical and temperate soils. Rev. Microbiol., 28: 5-10.

12. Grisi, B.M.; Grace, C.; Brookes, P.C.; Benedetti, A.; Dell'Abate, M.T. (1998). Temperature effects on organic matter and microbial biomass dynamics in temperate and tropical soils. Soil Biol. Biochem., 30: 1309-1315.

13. Hassink, J. (1994). Effects of soil texture and grassland management on soil organic $\mathrm{C}$ and $\mathrm{N}$ and rates of $\mathrm{C}$ and $\mathrm{N}$ mineralization. Soil Biol. Biochem., 26: 1221-1231.

14. Insam, H.; Parkinson, D.; Domsch, K.H. (1989). Influence of macroclimate on soil microbial biomass. Soil Biol Biochem., 21: 211-221.

15. Jenkinson, D.S.; Powlson, D.S. (1976). The effects of biocidal treatments on metabolism in soil. V. A method for measuring soil biomass. Soil Biol. Biochem., 8: 209-213.

16. Jenkinson, D.S.; Ladd, J.N. (1981). Microbial biomass in soil: measurement and turnover. In: Paul, E.A. (ed.) Soil Biochemistry, v. 5. Marcel Dekker, New York, pp. 415-471.

17. Kauffman, J.B.; Sanford, R.L.; Cummings, D.L.; Salcedo, I.H.; Sampaio, E.V.S.B. (1993). Biomass and nutrient dynamics associated with slash fires in neotropical dry forests. Ecology, 74: 140-151.

18. Ladd, J.N.; Amato, M.; Ki-Kai, Z.; Schults, J.E. (1994). Differential effects of rotation, palnt residue and nitrogen fertilizer on microbial biomass and organic matter in an Australian Alfisol. Soil Biol. Biochem., 26: 821-831.

19. Luna, R.G.; Grisi, B.M. (1996). Biomassa e atividade microbianas de solos cultivados com cana-de-açúcar, sob efeito de vinhaça. Rev. Nordest. Biol., 11: 15-29.

20. Odum, E. (1985). Trends expected in stressed ecosystems. Bio Science, 35: 419-422.
21. Paul, D.S.; Clark, F.E. (1989). Soil Microbiology and Biochemistry. Academic Press, San Diego.

22. Powlson, D.S.; Brookes, P.C.; Christensen, B.T. (1987). Measurement of soil microbial biomass provides an early indication of changes in total soil organic matter due to straw incorporation. Soil Biochem., 19: 159-164.

23. Santos, O.M.; Grisi, B.M. (1981). Efeito do desmatamento na atividade dos microorganismos de solo de terra-firme na Amazônia. Acta Amazonica, 11: 97-102.

24. Silva, G.G. (1993). A problemática da desertificação no Ecossistema da Caatinga do Município de São João do Cariri. Desert (Universidade Federal do Piauí), Teresina, Piauí.

25. Smith, J.L.; Paul, E.A. (1990). The significance of microbial biomass estimations. In: Bollag, J.M., Stotzoky, G. (eds.) Soil Biochemistry, v. 6. Marcel Dekker, New York, pp. 357-396.

26. Smith, J.L.; Halvorson, J.L.; Bolton, H.Jr. (1994). Spatial relationships of soil microbial biomass and $\mathrm{C}$ and $\mathrm{N}$ mineralization in a semi-arid shrub-steppe ecosystem. Soil Biol. Biochem., 26 1151-1159.

27. Srivastava, S.C.; Singh, J.S. (1991). Microbial C, N, and P in dry tropical Forest soil: effects of alternate land-uses and nutrient flux. Soil Biol. Biochem., 23: 117-124.

28. Stotzky, G. (1997). Quantifying the methabolic activity of microbes in soil. In: Hurst, C.J., Knunsen, G.R., McInerney, M.J., Stetzenbach, L.D., Walter, M.V. (eds.) Manual of Environmental Microbiology. American for Microbiology Press, Washington, pp. 453-458.

29. Vance, E.D.; Brookes, P.C.; Jenkinson, D.S. (1987). Microbial biomass measurements in forest soil: determination of $\mathrm{K}_{\mathrm{C}}$ values and tests of hypotheses to explain failures of the chloroform fumigationincubation method in acid soil. Soil Biol. Biochem., 19: 689-696.

30. Wardle, D.A.; Ghani, A.A. (1995). Critique of the microbial metabolic quotient $\left(\mathrm{qCO}_{2}\right)$ as bioindicator of disturbance and ecosystem development. Soil Biol. Biochem., 27: 1601-1610.

31. Walter, H.; Haber, H. (1957). Über die Intesität der Bodenatmung mit Benerkingenzu den lundegardschen Werten. Ber. Deut. Des., 70: 275-282. 